\title{
An investigation of winter minimum temperatures in the mountains of Montenegro - a case study from the karst depression of Valoviti Do and selected mountain stations of northern Montenegro
}

\author{
Matej Ogrin' ${ }^{A}$, Gojko Nikolić ${ }^{B}$, Darko Ogrin'A, Tajan Trobec ${ }^{A}$ \\ Received: June 21, 2018 | Revised: October 27, 2018 | Accepted: October 29, 2018 \\ DOI: $10.5937 / g p 22-18017$
}

\begin{abstract}
This article presents the findings from measurements of winter minimum temperatures taken over a period of several years in the high mountain karst depression of Valoviti Do on the Durmitor massif (Montenegro), and compares them with temperatures measured in the network of official stations operated by the Montenegro Hydrometeorological Institute. We took into consideration meteorological stations that are located in the coldest sites of Montenegro. The results of the measurements showed that winter minimum temperatures in high mountain depressions of Montenegro are considerably lower than the temperatures measured in the framework of the national network of meteorological stations, which are rarely located in the mountain environment. In the course of taking measurements in five nonconsecutive winter seasons in the period from 2007 to 2015 we also measured the lowest temperature recorded to date in Montenegro, $-40^{\circ} \mathrm{C}$.
\end{abstract}

Keywords: minimum temperatures; local climate; mountain climate; Durmitor; Montenegro

\section{Introduction}

Very little of the area of the country of Montenegro is found at low elevations due to the narrowness of its coastal zone and its highly dissected relief. Only 10\% of the territory is located at an elevation lower than $200 \mathrm{~m}$, whereas $55 \%$ of the territory is above $1000 \mathrm{~m}$ and $15 \%$ is above $1500 \mathrm{~m}$. The mean elevation in the country is $1050 \mathrm{~m}$ (Radojčić, 2008), ranking it third in Europe according to elevation. But despite a large portion of the area lying at higher elevations, there are few temperature stations at higher elevation sites in Montenegro. The highest main meteorological station, which is also the highest meteorological station in Montenegro, is located at an elevation of $1450 \mathrm{~m}$ on Žabljak, on the Jezera Plateau (Jezerska Površ) at the edge of the Durmitor Massif in the northern part of the country. Of the remaining meteorological stations that also measure air temperature, only two lie at an elevation above $1000 \mathrm{~m}$, the Rožaje meteorological station (1007 m) and the Krstac meteorological station $(1017 \mathrm{~m})$. This means that for the $15 \%$ of the territory of

\footnotetext{
A Department of Geography, Faculty of Arts, University of Ljubljana, matej.ogrin@ff.uni-lj.si, darko.ogrin@ff.uni-lj.si, tajan. trobec@ff.uni-lj.si

B Department of Geography, Faculty of Arts, University of Montenegro, gojkorn@t-com.me

* Corresponding author: Gojko Nikolić; e-mail: gojkorn@t-com.me
} 
Montenegro that lies at the highest elevations there is no corresponding meteorological station, and for $55 \%$ of the territory there are only three. From the standpoint of temperature conditions, which are dependent in large measure on the variability of the relief and elevation, this means that the overview of temperature conditions in the mountain environment of Montenegro that we obtain based on data from the official network of meteorological stations is deficient and that actual conditions may diverge considerably from official data. Based on measurements from mountain regions of other parts of the world we know that in concave areas nighttime and hence minimum temperatures in particular can drop quite low locally, considerably lower than the usual temperatures at that elevation. This has been shown by studies in the USA (e.g. Lareau et al., 2013; Whiteman et. al., 1999) and the European Alps (Schmidt, 1930; Whiteman et al. 2004a; Whiteman et. al. 2004b; Ogrin et al., 2006, Ogrin, 2008; Trošt, 2008; Ortar 2011), from Hungary (e.g. Barany - Kevei, 1999), and examples from the Dinaric range are also described (e.g. Gams, 1972; Martinčič, 1975, 1977; Ortar, 2011). These colder temperatures are caused by the creation of cold air lakes in concave relief landforms, for which there are numerous studies, (e.g. Petkovšek, 1978; Müller in Whiteman,1988; Zhong et. al., 2001; Clements et al., 2003; Ogrin D., Ogrin M., 2005), while other atmospheric conditions, particularly a lower radiation balance, also contribute significantly to lower temperatures.

Concave relief forms are common features of the karst environment, in which water dissolves the limestone through corrosion and flows vertically into the ground. Examples of this form of relief are uvalas, dolines, collapse dolines, snow kettles from the corrosion of snowmelt, and through tectonic processes also poljes and elongated lowlands. Concave relief forms are also found in non-karst areas, for example in areas that have undergone glacial transformation. Depression landforms are often created behind terminal moraines. In areas where glaciers or snow cover are at work, nivation hollows can form (Natek, 2007). In a volcanic type of surface inactive volcanic craters are also an example of a concave surface.

Most of the surface of the territory of Montenegro is composed of carbonate rock. These are the mountain systems of Lovčen, Orjen, Rumija, Durmitor, the Morača Mountains, Maganik, Sinjajevina, Komovi, Prokletije, the Piva Mountains and others, where there are numerous karst depressions of varying sizes, in which cold air lakes are created during an anticyclonal type of weather. For this reason the minimum temper- atures are certainly lower here than those outside the depressions, but conditions have not yet been investigated in more detail. The objective of this article is thus to present the results of measurements over a number of years in a high mountain karst depression, Valoviti Do on Durmitor, and thereby contribute to a better understanding of temperature conditions in the mountains of Montenegro. At the same time we also wanted to compare our measurements with the lowest temperatures measured to date within the country's national network of meteorological stations. Specifically, we hypothesized that temperatures in Montenegro could be considerably lower than those measured to date, since data from concave relief forms of mountain regions above about $1500 \mathrm{~m}$ elevation are not available. The sole work treating this problem was carried out by Ortar et al. (2010). The work arose at the outset of research studies on minimum temperatures by the Slovenian Meteorological Forum in collaboration with geographers from the University of Ljubljana in Valoviti Do on Durmitor and the karst depression Reovce on Orjen. The first measurements confirmed Valoviti Do as a very advantageous location for research of this kind, and so we continued taking measurements. These are presented in this paper.

Đurović (2012) has written about the mountain climate of Montenegro, with an emphasis on the climate of Durmitor, as part of a study dealing with geomorphological and glaciological phenomena of Durmitor's only glacier, Debeli Namet. To show temperature conditions he used data from the Žabljak meteorological station and high mountain stations in Slovenia and Bulgaria, but not at the level of local climate. In a research monograph devoted to the high mountain karst of Durmitor (Đurović, 2011), the same author also described the climate of Durmitor in a separate chapter with an emphasis on vertical temperature gradients, amount of precipitation, and temperature trends in the period from 1960 to 1993.

The main purpose of this article is to show the temperature conditions in the frost hollow of Valoviti Do on Durmitor through an analysis of multi-year measurements and compare these measurements with the lowest recorded temperatures in mountain areas of Montenegro. Our aim is to draw attention to the extreme variability of temperature conditions in the mountain environment, which are due not just to elevation and continentality but also to relief formation at the micro and meso levels. Since Montenegro is a distinctly mountainous country, it can be assumed that such conditions are also present in mountain areas outside the study area. 


\section{Research area}

Durmitor is a mountain massif in the northern part of Montenegro, the highest range in the country after Prokletije. The highest summit is Bobotov Kuk (el. $2523 \mathrm{~m}$ ); geologically it is part of the Dinaric chain that winds southwest from the Julian Alps in Slovenia towards the Prokletije range on the border between Montenegro and Albania. It is composed of carbonate rocks (Đurović, 2009), primarily limestone, that were uplifted during the Alpide orogeny (Morley, 2007, cited in: Annys et. al., 2014). Due to the geological composition and the high elevation, numerous karst, glacial, and periglacial relief forms can be found in this region (Annys et al., 2014)

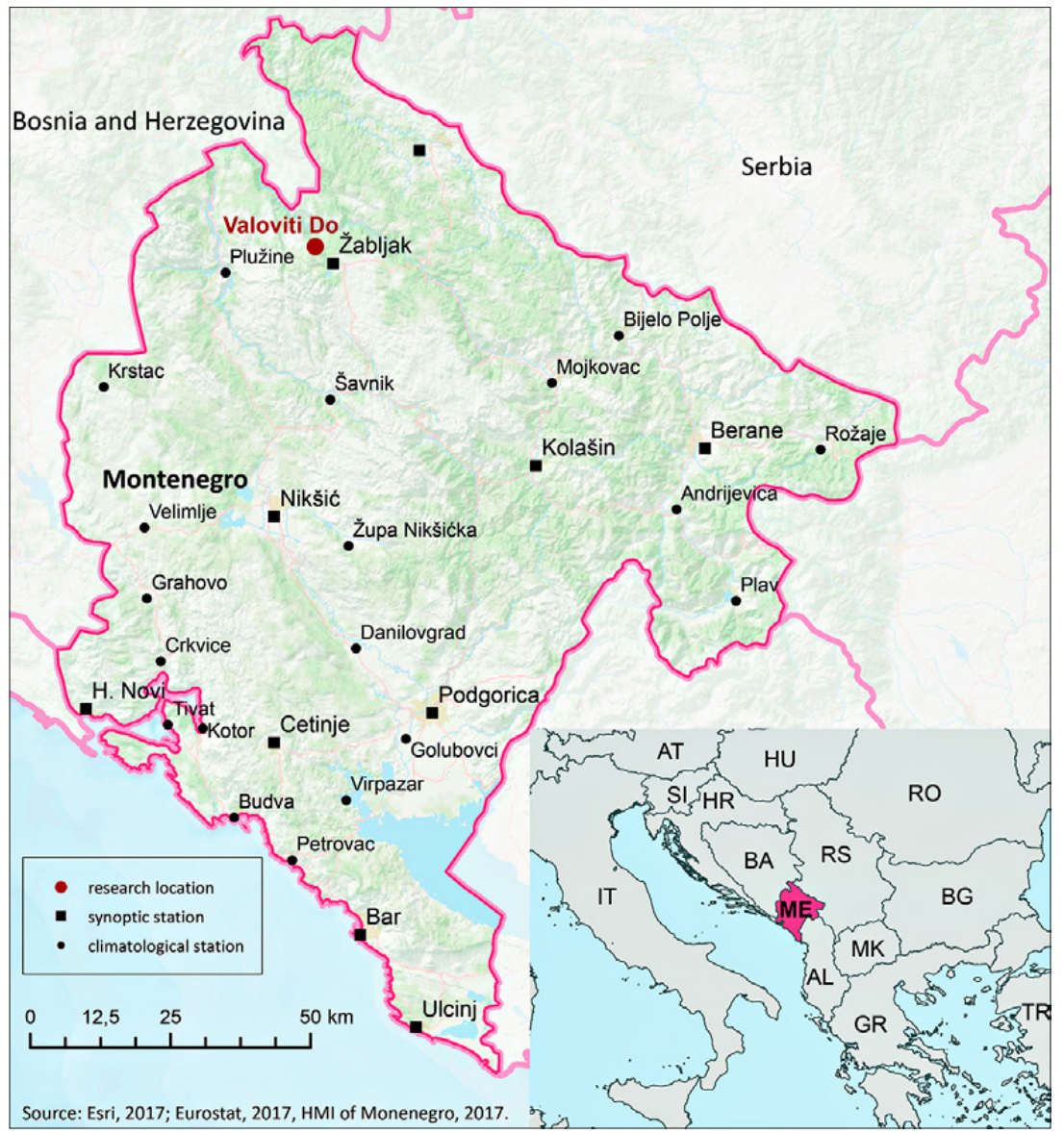

Figure 1. The research area with the spatial distribution of meteorological stations with temperature measurements in Montenegro Source: A. Seifert

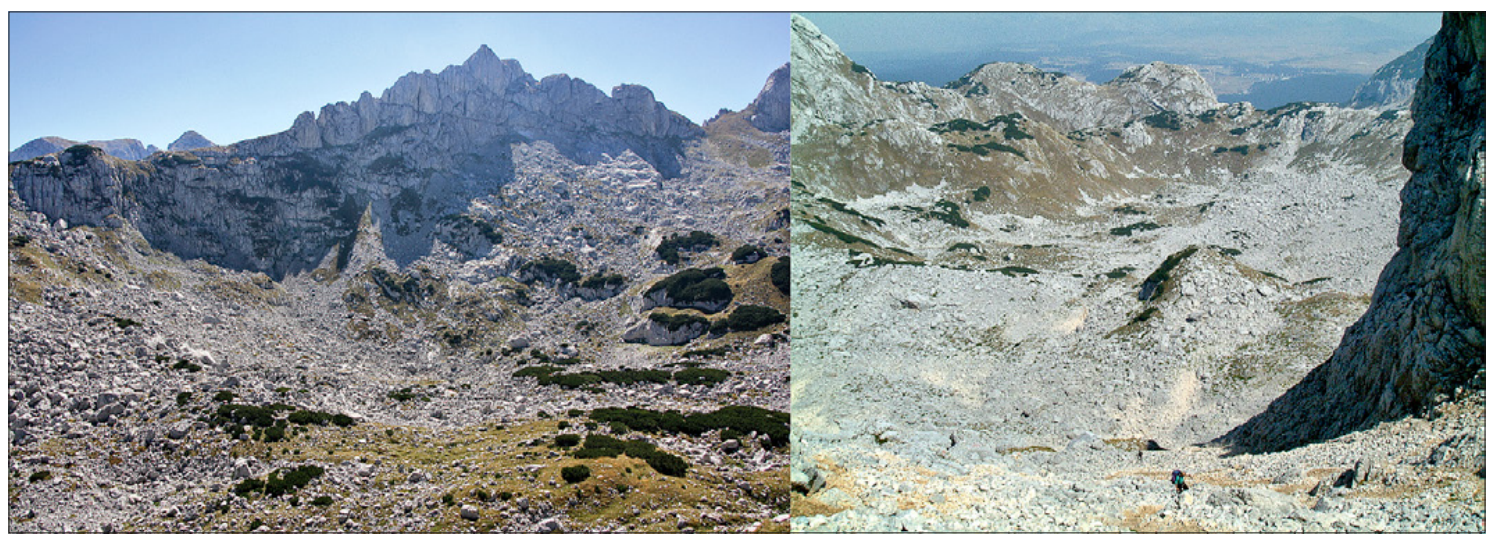

Figure 2. Valoviti Do from the (a) western and (b) northern rims 


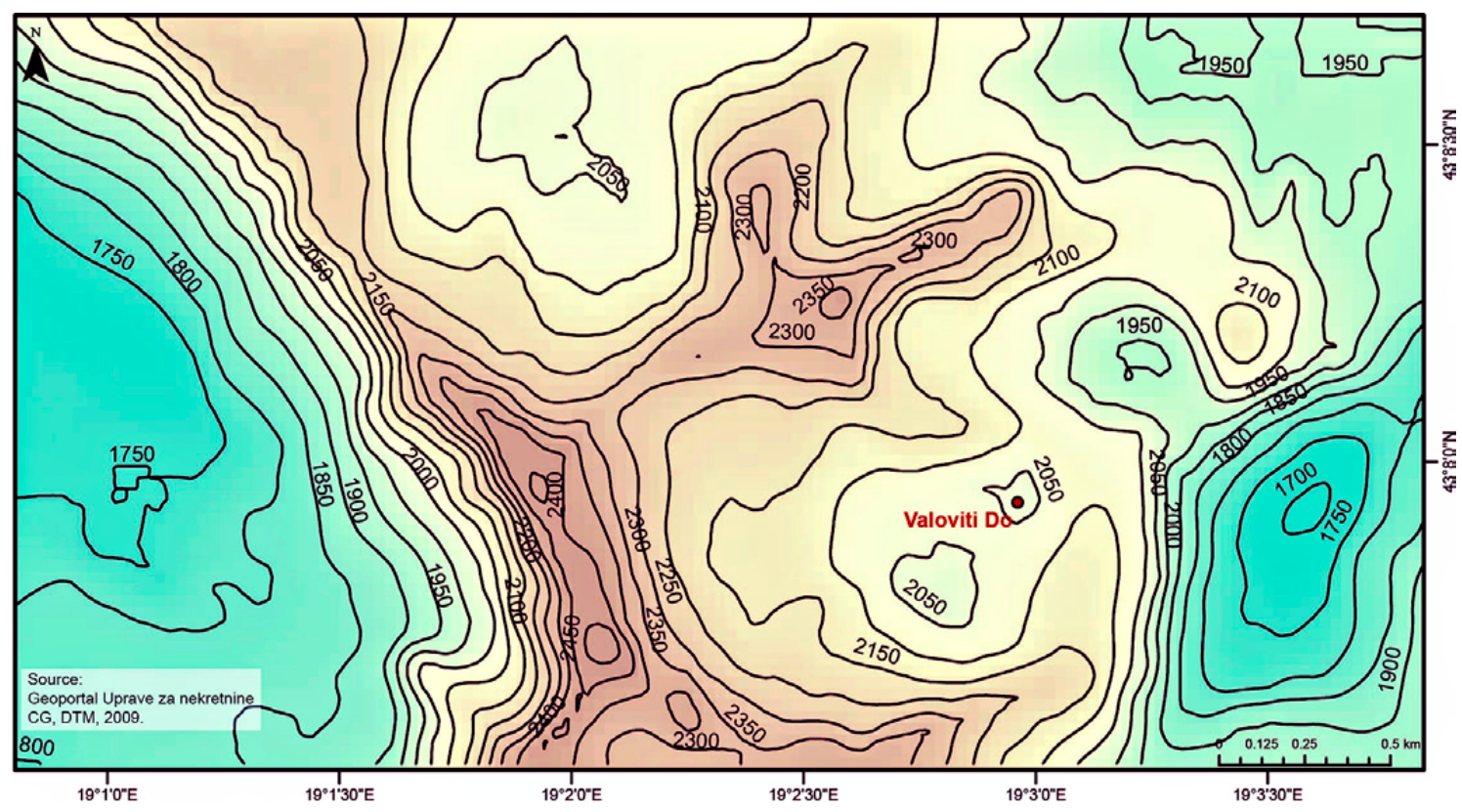

Figure 3. Hypsometry of Valoviti Do

Source: A. Seifert

Valoviti Do is a high mountain karst depression in the central part of the Durmitor massif. The floor of the depression lies at an elevation of $2018 \mathrm{~m}$, and is encircled to the west by the highest summits of Durmitor, such as Bobotov Kuk (el. 2523 m), Bezimeni Vrh (el. $2487 \mathrm{~m}$ ) and Lučin Vrh (el. $2396 \mathrm{~m}$ ), to the south by Minin Bogaz (el. $2387 \mathrm{~m}$ ), and to the east by Pasovi and Sagorele Ploče (el. $2120 \mathrm{~m}$ ). The eastern rim of the depression is also the lowest and hence where cold air flows out from the depression at an elevation of somewhat less than $2100 \mathrm{~m}$. The depression floor is highly dissected with fallen blocks of rock, and the depression is regularly filled by snow avalanches triggered from the slope of Minin Bogaz, forming snowfields that last into late summer. The floor of the basin is about $220 \mathrm{~m}$ wide and about $300 \mathrm{~m}$ long.

\section{Overview of temperatures in Montenegro, with special reference to minimum air temperatures}

Detailed studies of global warming have been done for the Alps, but such studies have not yet been conducted for the Dinaric mountains. There was, however, a study carried out for the Montenegrin part of this mountain chain from 1951 to 2008 by by Burić et al. (2011). For the Alpine region an annual warming trend over the last century of about 0.12 to $0.2{ }^{\circ} \mathrm{C}$ per decade has been detected, and the trend is especially pronounced from the 198 os on (Brönnimann et. al., 2014). For the region of the Montenegrin mountains (Table 2) an annual warming trend from 1950 to 2008 is similar to those in the Alps, with a statistical level of confidence of $95 \%$ for six out of seven stations.

Table 1 displays data on average annual temperatures at meteorological stations in the interior of Montenegro, categorized according to elevation. The vertical temperature gradient for the average annual air temperature calculated for these stations is -0.45 $\mathrm{K} / 100 \mathrm{~m}\left(\mathrm{R}^{2}=0.4347\right)$,which is less than if we include in the analysis all available Montenegrin meteorological stations for the period from 1951 to 2008 . In that
Table 1. Average annual air temperatures (AAAT) at meteorological stations in the interior part of Montenegro for the period 1951 - 2008)

\begin{tabular}{|l|c|c|}
\hline Meteorological station & Elevation $(\mathrm{m})$ & AAAT $\left({ }^{\circ} \mathrm{C}\right)$ \\
\hline Žabljak & 1450 & 5.1 \\
\hline Kolašin & 944 & 7.3 \\
\hline Pljevlja & 784 & 8.4 \\
\hline Berane & 691 & 9.2 \\
\hline Bijelo Polje & 606 & 9.1 \\
\hline Cetinje & 640 & 10.1 \\
\hline Nikšić & 647 & 11.0 \\
\hline
\end{tabular}

Source: Burić et al., 2011

case the gradient is $-0.66 \mathrm{~K} / 100 \mathrm{~m}\left(\mathrm{R}^{2}=0.8005\right)$. The lower gradient is the result of the location of the majority of stations in the interior of Montenegro in river valleys or basins, where temperature inversions frequently occur. This is not the case for the highest station of Žabljak, which is located outside the local cold air lake. 
Table 2. Statistical trends and statistical significance of temperature change in Montenegrin mountain areas in the period from 1951 to 2008

\begin{tabular}{|l|c|c|c|c|c|}
\hline \multirow{2}{*}{ Station } & \multirow{2}{*}{$\begin{array}{c}\text { Trend AAAT } \\
\left({ }^{\circ} \mathrm{C} / 10 \text { years }\right)\end{array}$} & \multicolumn{4}{|c|}{ Statistical significance (T test) } \\
\cline { 3 - 6 } & 0.168 & 0.10 & 0.05 & 0.02 & 0.01 \\
\hline Žabljak & 0.114 & yes & yes & yes & yes \\
\hline Kolašin & 0.116 & yes & yes & yes & no \\
\hline Pljevlja & 0.169 & yes & yes & yo & no \\
\hline Berane & 0.113 & yes & yes & no & yes \\
\hline Bijelo Polje & -0.034 & no & no & no & no \\
\hline Cetinje & 0.106 & yes & yes & yes & no \\
\hline Nikšić & & & & & \\
\hline
\end{tabular}

Source: Burić et. al., 2011

For the purposes of this study, we performed a statistical analysis of the minimum temperatures for the meteorological stations Kolašin, Rožaje and Žabljak from 1970 to 2016. The analysis was carried out using the Mann-Kendall test, which also confirmed warming trends with respect to the minimum temperatures in mountain areas of Montenegro (Table 3). Table 3 shows that all trends are positive with respect to the Mann-Kendall test (positive Sen's slope) and sta- tistically significant, and the level of confidence is very high.

It is clear from an analysis of the official data on the absolute lowest temperatures in Montenegro, which we obtained with the help of the Montenegro Hydrometeorological Institute, that the effect of the temperature inversion is even more pronounced. The first seven officially lowest temperatures in Montenegro were measured at meteorological stations that lie in basins or val-

Table 3. Statistical trends and statistical significance of minimum temperatures at Kolašin, Rožaje and Žabljak from 1960 to 2017

\begin{tabular}{|l|c|c|c|c|c|c|c|}
\hline Station & Period & $\begin{array}{c}\text { Mann-Kendall } \\
\text { test [Z] }\end{array}$ & $\begin{array}{c}\text { Level of } \\
\text { confidence [\%] }\end{array}$ & $\begin{array}{c}\text { Sen's slope } \\
{[\mathrm{Q}]}\end{array}$ & $\begin{array}{c}\text { Initial state } \\
{\left[{ }^{\circ} \mathrm{C}\right]}\end{array}$ & $\begin{array}{c}\text { Final state } \\
{\left[{ }^{\circ} \mathrm{C}\right]}\end{array}$ & $\begin{array}{c}\text { Trend } \\
{\left[{ }^{\circ} \mathrm{C}\right]}\end{array}$ \\
\hline Kolašin* & $1960-2017$ & 2.77 & 99 & 0.022 & -5.73 & -4.5 & 1.23 \\
\hline Rožaje** & $1970-2017$ & 6.03 & 99.9 & 0.103 & -8.86 & -4.02 & 4.84 \\
\hline Žabljak & $1960-2017$ & 4.35 & 99.9 & 0.037 & -8.18 & -6.09 & 2.09 \\
\hline
\end{tabular}

* not including 1997, ** not including 1969

Table 4. Absolute minimum temperatures in Montenegro in the period from 1950 to 2016

\begin{tabular}{|l|c|c|c|}
\hline $\begin{array}{l}\text { Meteorologi- } \\
\text { cal station }\end{array}$ & $\begin{array}{c}\text { Elevation } \\
(\mathrm{m})\end{array}$ & $\begin{array}{c}\text { Absolute mini- } \\
\text { mum tempera- } \\
\text { ture }\left({ }^{\circ} \mathrm{C}\right)\end{array}$ & Date \\
\hline Rožaje & 1007 & -32.0 & 13 Jan 1985 \\
\hline Kolašin & 944 & -29.8 & 13 Jan 1985 \\
\hline Plav & 933 & -29.8 & 13 Jan 1985 \\
\hline Pljevlja & 784 & -29.4 & 26 Jan 1954 \\
\hline Berane & 691 & -28.3 & 13 Jan 1985 \\
\hline Bijelo Polje & 606 & -27.6 & 26 Jan 1954 \\
\hline Grahovo & 695 & -26.8 & 12 Jan 1985 \\
\hline Žabljak & 1450 & -26.4 & 25 Jan 1963 \\
\hline Mojkovac & 848 & -25.6 & 26 Jan 2006 \\
\hline Velimlje & 833 & -25.0 & 12 Jan 1985 \\
\hline Šavnik & 825 & -24.3 & 26 Jan 2000 \\
\hline Andrijevica & 772 & -23.8 & 20 Jan 2006. \\
\hline Krstac & 1017 & -23.4 & 13 Jan 1985 \\
\hline Cetinje & 640 & -22.8 & 26 Jan 2000 \\
\hline Crkvice & 937 & -22.0 & 05 Jan 1980 \\
\hline
\end{tabular}

\begin{tabular}{|l|c|c|c|}
\hline $\begin{array}{l}\text { Meteorologi- } \\
\text { cal station }\end{array}$ & $\begin{array}{c}\text { Elevation } \\
(\mathrm{m})\end{array}$ & $\begin{array}{c}\text { Absolute mini- } \\
\text { mum tempera- } \\
\text { ture }\left({ }^{\circ} \mathrm{C}\right)\end{array}$ & Date \\
\hline Nikšić & 647 & -20.2 & 13 Jan 1985 \\
\hline Plužine & 780 & -20.1 & 26 Jan 2000 \\
\hline Župa Nikšićka & 789 & -17.0 & 17 Feb 2012 \\
\hline Danilovgrad & 53 & -14.6 & 13 Jan 1985 \\
\hline Virpazar & 14 & -13.5 & 26 Jan 2000 \\
\hline Golubovci & 33 & -12.0 & 13 Jan 1985 \\
\hline Podgorica & 49 & -9.7 & 04 Feb1956 \\
\hline Budva & 2 & -8.5 & 14 Jan 1968 \\
\hline Ulcinj & 29 & -8.4 & 23 Jan 1963 \\
\hline Tivat & 5 & -8.2 & 03 Feb 1991 \\
\hline Bar & 6 & -7.2 & 23 Jan 1963 \\
\hline Herceg Novi & 10 & -7.0 & 13 Jan 1985 \\
\hline Petrovac & 5 & -5.0 & 13 Feb 2004 \\
\hline Kotor & 1 & -4.2 & 04 Jan 1979 \\
\hline
\end{tabular}

Source: Montenegro Hydrometeorological Institute, 2016 
leys, whereas the highest lying station of Žabljak (el. $1450 \mathrm{~m}$ ), which otherwise stands out for having the lowest average annual temperature, is only in eighth place. As mentioned, this is the only station that lies outside the local cold air lake. Table 4 shows that the officially lowest temperature in Montenegro was measured in Rožaje in the extreme eastern part of the country. On
13 January 1985 a temperature of $-32{ }^{\circ} \mathrm{C}$ was measured here, followed by the valley or basin stations of Kolašin and Plav $\left(-29.8^{\circ} \mathrm{C}\right)$, Pljevlja $\left(-29.4^{\circ} \mathrm{C}\right)$, Berane $\left(-28.3^{\circ} \mathrm{C}\right)$ and Bijelo Polje $\left(-27.6^{\circ} \mathrm{C}\right)$, all of which are located in the east or north of the country. Only Grahovo $\left(-26.8^{\circ} \mathrm{C}\right)$ is a karst polje in the west of the country, less than $20 \mathrm{~km}$ distant from the sea.

\section{Methodology for measuring minimum temperatures in Valoviti Do}

We carried out temperature measurements in the frost hollow of Valoviti Do using an iButton digital temperature sensor, manufactured by the company Dallas Semiconductor. The device begins recording temperature at a predetermined time and at selected time intervals. In our case the time interval was set at $30 \mathrm{~min}$ utes in one season (winter 2007/2008), at 15 minutes in three seasons (2010/2011, 2011/2012, 2014/2015), and at ten minutes in the 2012/2013 season. In this season the measuring instrument Madgetech Cryo Temp Data Logger was used. The Dallas Semiconductor sensor records temperatures to $-41^{\circ} \mathrm{C}$, and the confidence interval is from -0.9 to $+1.6{ }^{\circ} \mathrm{C}$ at the lowest temperatures and from -0.7 to $+1.2{ }^{\circ} \mathrm{C}$ at a temperature of $-30{ }^{\circ} \mathrm{C}$ (Ogrin, 2007), while the measuring range for the Data Logger Cryo Temp extends to $-86^{\circ} \mathrm{C}$, with an accuracy of $\pm 1^{\circ} \mathrm{C}$. The precision of measurements was set to $0.5^{\circ} \mathrm{C}$.

The temperature sensor was mounted on a pole and protected from the weather by a specially made shelter (see also Ogrin, 2007). The shelter was constructed so as to conform as closely as possible to the standards of the World Meteorological Organization - it is made from materials with low thermal capacity and conductivity and high reflectivity (Ogrin et al., 2006).
The shelter and temperature sensor were installed in the lowest part of the frost hollow at a height of 4 - 5 $\mathrm{m}$ above the ground so that it would not be buried by a high snow cover. During periods of heavy snowfall the height of the shelter above the ground was considerably lower, and in the event of a snow avalanche the measuring apparatus could also be knocked over and buried by snow, which would mean an end to the measuring.

Measurements were carried out in the winters of 2007/2008, 2010/2011,2011/2012, 2012/2013 and 2014/2015. Measurements took place from the end of October to the end of March and in some cases into April. Data from November, December, January, February and March were included in the analysis. Due to incompleteness of the time series, we excluded the winter of 2012/2013 from the calculation of average temperatures since an avalanche in February knocked down and buried the measuring apparatus. The time series of measurements in Valoviti Do was not always complete. In November 2007 measurements were performed for 28 days $(3-30$ November 2007) and in March 2011 for only 25 days ( $1-25$ March 2011).

We then compared the measurements from Valoviti Do with data from the stations in the network

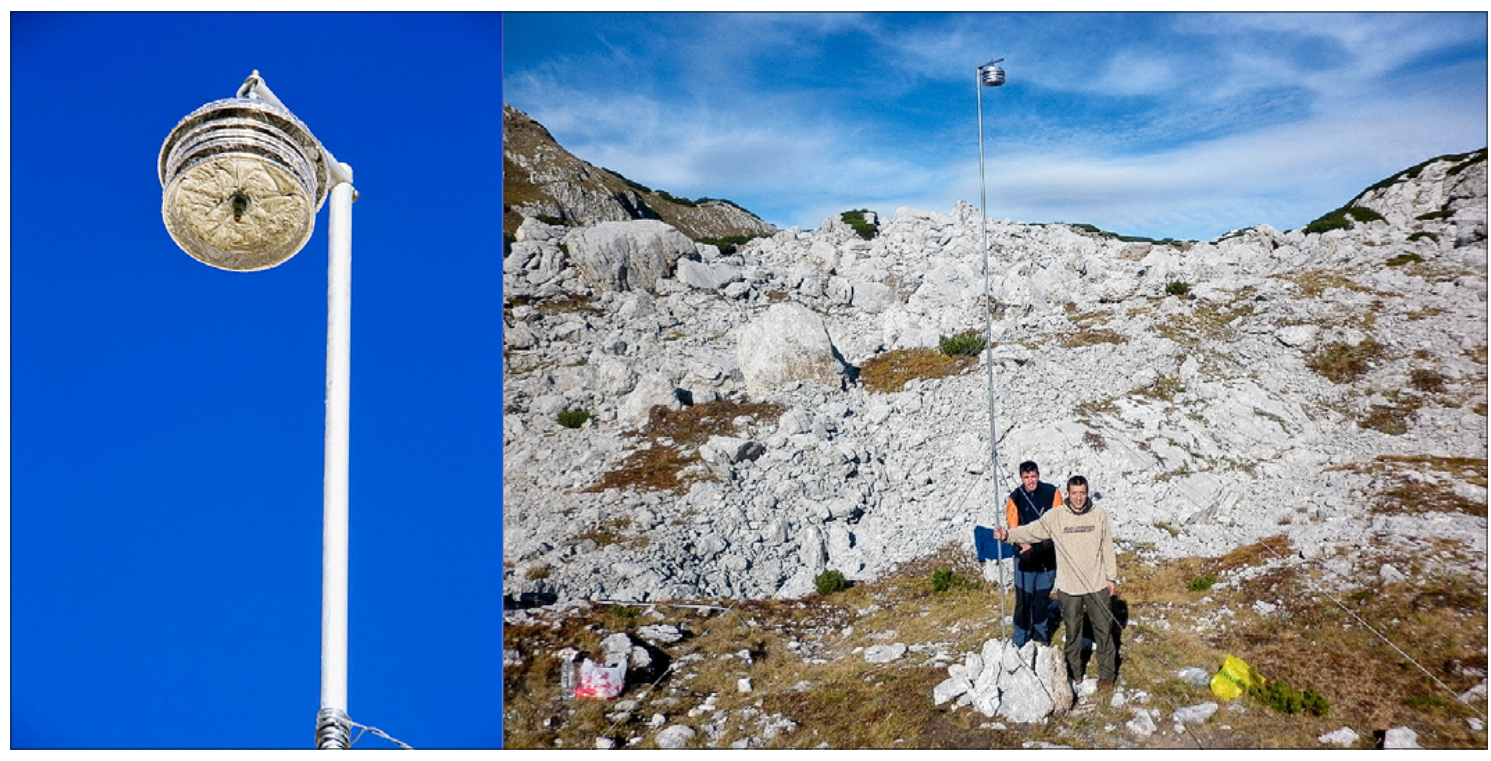

Figure 4. Measuring apparatus for the air temperature in Valoviti Do 
of the Montenegro Meteorological Service that are among the coldest in Montenegro: Rožaje, Kolašin and Žabljak. We collected data for the same period in which our measurements took place. Data were taken from the Montenegro Hydrometeorological Insti- tute and the analysis included absolute minimum air temperatures and average minimum temperatures; we also calculated the arithmetic mean of the absolute lowest temperatures by month and the arithmetic mean of the average minimum temperatures.

\section{Results and discussion}

\section{Absolute minimum air temperatures}

Conducive conditions for minimum temperatures are created by the influence of relief and atmospheric factors. Atmospheric factors conducive to low temperatures are associated with the inflow of dry, cold air masses that most commonly flow in above the Balkan Peninsula from the polar or even Arctic part of Northern Europe. These penetrations are related to the interruption of a zonal circulation pattern, the breakdown of the polar vortex, and the creation of a northern stream of air above Central Europe lasting several days, reaching to the Balkan Peninsula. Conditions for the breakdown of the polar vortex are well described by the North Atlantic Oscillation (NAO). The NAO is described by an index which measures the difference in sea level pressure between Iceland and Azores (Hurrell 1995). Large differences in air pressure influence the formation of prevailing winds above Europe, which particularly in winter have an impact on whether winters in Eurasia will be warmer or colder. The greater the difference in the air pressure, the stronger the westerly winds above Europe, and vice versa. A positive value of the NAO Index means on average warmer winters, while a negative value means colder ones, with frequent breakdowns of the polar vortex. The values of the NAO Index during the winters during which our study took place are presented in Table 5.
This is greater at higher elevation locations, where atmospheric radiation is less. However, the morphology of the area also has an influence. Concave relief forms without an outflow of air from the lowest part can retain cold air all night long and this continues to have a cooling effect. Moreover, the openness of the depression and the sky view factor are also important. This represents the proportion of density of long-wave radiation that falls from the visible part of the sky onto a horizontal surface with respect to a theoretical case with a mathematical horizon (Dozier and Frew, 1990, cited in Ortar, 2011).

Concave forms with a greater sky view factor cool off more quickly and hence reach a lower temperature than more closed forms (Whiteman et al., 2004b). Three of the measuring spots treated are located in concave relief forms; these are Rožaje, Kolašin and Valoviti Do. The meteorological stations Rožaje and Kolašin are in a valley, while Valoviti Do is in a high mountain karst depression. The station Žabljak is located in a plateau-like slightly raised environment and is not subjected to the effects of a cold air lake.

It is clear from the data in Tables 7, 8, 9 and in Figures 5 and 6 that the minimum temperatures at the meteorological stations Rožaje, Kolašin and Žabljak are to some extent similar, while the measuring spot of Valoviti Do often stands out for its very low temperatures.

Table 5. Values of the North Atlantic Oscillation Index for particular years of the study

\begin{tabular}{|l|c|c|c|c|c|}
\hline Winter (D, J, F) & $2007 / 2008$ & $2010 / 2011$ & $2011 / 2012$ & $2012 / 2013$ & $2014 / 2015$ \\
\hline NAO & 0.65 & -0.67 & 1.37 & 0.02 & 1.65 \\
\hline
\end{tabular}

Source: National Prediction Center, 2018

In the case of measurements of absolute minimum temperatures, one strong penetration in winter is sufficient, and this is also possible during periods when the value of the NAO is positive, but the probability for low minimums is higher during periods when the value of the NAO is negative. In our case we see that the lowest temperature measured in the high mountain frost hollow occurred in the winter with the lowest NAO value, but this was not the case for the other stations.

Absolute minimum air temperatures primarily show us the cooling potential of a particular location.
In all months the lowest temperature was measured in Valoviti Do (Table 6, Figure 5). In only one instance (January 2015) was the difference from the second coldest station (Rožaje) minimal $\left(0.1^{\circ} \mathrm{C}\right)$, while the largest difference was as much as $22.8^{\circ} \mathrm{C}$ (January 2011). When minimum temperatures in Valoviti Do are similar to those at lower lying meteorological stations, it is the case that cooling in Valoviti Do was disrupted by wind or clouds when these disturbances were not present at Rožaje. Of sixteen winter months, in six of the months the difference was smaller than $10^{\circ} \mathrm{C}$ and in ten of the months it was greater than $10^{\circ} \mathrm{C}$. 

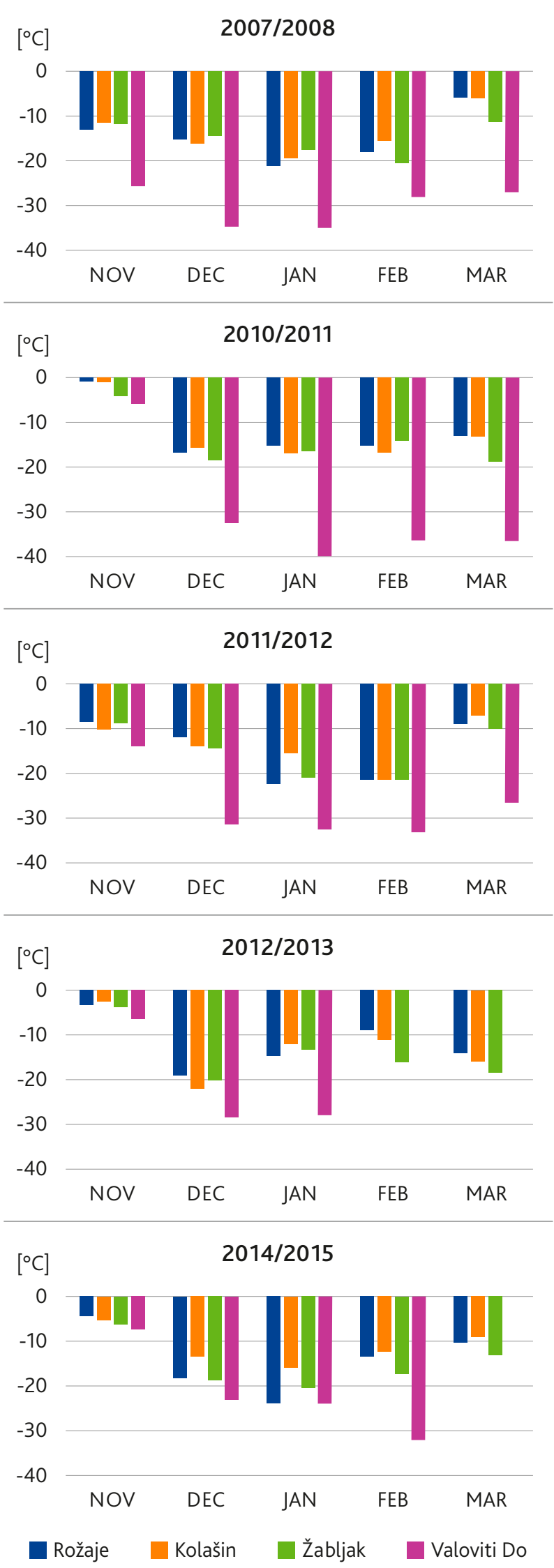

Figure 5. Lowest monthly air temperatures $\left({ }^{\circ} \mathrm{C}\right)$ at the meteorological stations of Rožaje, Kolašin and Žabljak and at the measuring spot of Valoviti Do in the 2007/2008, 2010/2011, 2012/2013 and 2014/2015 seasons
Table 6. Lowest monthly air temperatures $\left({ }^{\circ} \mathrm{C}\right)$ at the meteorological stations of Rožaje, Kolašin and Žabljak and at the measuring spot of Valoviti Do in the 2007/2008, 2010/2011, 2012/2013 and 2014/2015 seasons

\begin{tabular}{|l|c|c|c|c|c|}
\hline 2007/2008 & Nov* & Dec & Jan & Feb & Mar \\
\hline Rožaje & -12.9 & -15.3 & -21 & -18 & -5.9 \\
\hline Kolašin & -11.5 & -16.2 & -19.3 & -15.6 & -6.2 \\
\hline Žabljak & -11.7 & -14.4 & -17.6 & -20.5 & -11.3 \\
\hline Valoviti Do & -25.5 & -34.5 & -35 & -28 & -27 \\
\hline 2010/2011 & Nov & Dec & Jan & Feb & Mar** \\
\hline Rožaje & -1 & -16.9 & -15.5 & -15.5 & -13.1 \\
\hline Kolašin & -1.2 & -15.8 & -17.2 & -17.1 & -13.2 \\
\hline Žabljak & -4.3 & -18.6 & -16.7 & -14.2 & -19 \\
\hline Valoviti Do & -6 & -32.5 & -40 & -36.5 & -36.5 \\
\hline 2011/2012 & Nov & Dec & Jan & Feb & Mar \\
\hline Rožaje & -8.5 & -12 & -22.2 & -21.5 & -9 \\
\hline Kolašin & -10.1 & -13.8 & -15.5 & -21.3 & -7.3 \\
\hline Žabljak & -8.9 & -14.5 & -20.8 & -21.5 & -10.1 \\
\hline Valoviti Do & -14 & -31.5 & -32.5 & -33 & -26.5 \\
\hline 2012/2013 & Nov & Dec & Jan & Feb & Mar \\
\hline Rožaje & -3.5 & -19.1 & -14.6 & -9 & -14 \\
\hline Kolašin & -2.6 & -22 & -12 & -11.2 & -15.8 \\
\hline Žabljak & -3.8 & -20.2 & -13.4 & -16.2 & -18.4 \\
\hline Valoviti Do & -6.5 & -28.3 & -27.8 & & \\
\hline 2014/2015 & Nov & Dec & Jan & Feb & Mar \\
\hline Rožaje & -4.4 & -18.1 & -23.9 & -13.5 & -10.4 \\
\hline Kolašin & -5.4 & -13.5 & -16 & -12.5 & -9.2 \\
\hline Žabljak & -6.4 & -18.8 & -20.4 & -17.2 & -13.2 \\
\hline Valoviti Do & -7.5 & -23 & -24 & -32 & \\
\hline
\end{tabular}

*only 28 days in November 2007

**only 25 days in March 2011

The second coldest station was not always the same one. In fourteen instances the second coldest was Žabljak, but in five instances it was Kolašin or Rožaje, and in one instance the temperatures were the same at Rožaje and at Žabljak. If we look at the arithmetic mean of the absolute lowest temperatures for the months when measurements were taken (Table 7), we see that Valoviti Do was colder than the second coldest station Žabljak by $11.8^{\circ} \mathrm{C}$, but Žabljak was colder than Rožaje by only $0.4^{\circ} \mathrm{C}$. Kolašin, where the average lowest temperature during the period studied was $-13.9^{\circ} \mathrm{C}$, was warmer by a bit more than a degree $\left(1.1^{\circ} \mathrm{C}\right)$. We also measured the absolute lowest temperature measured anywhere to date in Montenegro at Valoviti Do. On 4 January 2011 it was $-40^{\circ} \mathrm{C}$ between 8:30 and 9:15, which is lower by $8{ }^{\circ} \mathrm{C}$ than the lowest recorded temperature in Montenegro up to that time, which was measured on 13 January 1985 in Rožaje, when it was $-32.0^{\circ} \mathrm{C}$ (HMZ $C G, 2017)$. The meteorological situation over Europe on 
that day was very conducive to low temperatures in the Balkan Peninsula. Cold polar air mas flowed to Scandinavia in the hinterland of the cyclone and from there the anticyclone situated over the Balkans brought this cold air to the Dinaric region. At an elevation of about $1500 \mathrm{~m}$, the temperature of the air mass in the area of Durmitor was around $-12{ }^{\circ} \mathrm{C}$, the sky was clear, and the atmosphere dry (Wetterzentrale, 2018).

Temperature differences can be explained by the location of the stations. Elevation plays a very important role, but location, or rather the degree of concavity or convexity of the surface where the meteorological station is located, is also important. For low minimums in addition to the higher elevation, the location in a concave relief form is also important. The measuring spot in Valoviti Do meets both conditions, since it is a high mountain frost hollow and with respect to minimum temperatures it is one of the coldest locations in Montenegro. This is not the case for the meteorological station of Žabljak, which is located on an elevated part of the plateau that is exposed to wind and is outside the local cold air lake. Cooling of air at night is often disturbed by wind. Thus the effect of higher elevation on minimum temperatures is weakened due to the microlocation. Although the stations of Rožaje and Kolašin lie 443 and 506 meters lower, respectively, than Žabljak, they are located in valleys with frequent and pronounced temperature inversions. Thus the phenomenon of the cold air lake is a cause for absolute minimum temperatures in winter being comparable with those at Žabljak.

Table 7. Average absolute minimum air temperatures $\left({ }^{\circ} \mathrm{C}\right)$ for the winter seasons 2007/2008, 2010/2011, 2011/2012 and 2014/2015

\begin{tabular}{|l|c|c|}
\hline Station & Elevation $(\mathrm{m})$ & $\mathrm{T}\left({ }^{\circ} \mathrm{C}\right)$ \\
\hline Rožaje & 1007 & -15.0 \\
\hline Kolašin & 944 & -13.9 \\
\hline Žabljak & 1450 & -15.4 \\
\hline Valoviti Do & 2018 & -27.2 \\
\hline
\end{tabular}

* In November 2007 measurements were performed for 28 days (3 - 30 November 2007) and in March 2011 for only 25 days (1-25 March 2011)

\section{Average minimum temperatures}

We calculated average minimum temperatures for a particular month as the arithmetic mean of the minimum daily temperatures in that month. An overview of average minimum temperatures also shows that the lowest values were to be found at Valoviti Do. For all the months studied the average minimum temperature was the lowest at Valoviti Do, in which the largest difference from the second coldest station was $8.4^{\circ} \mathrm{C}$ (February 2011) and the smallest was $1.5^{\circ} \mathrm{C}$ (November 2011). The average difference between Valoviti Do and
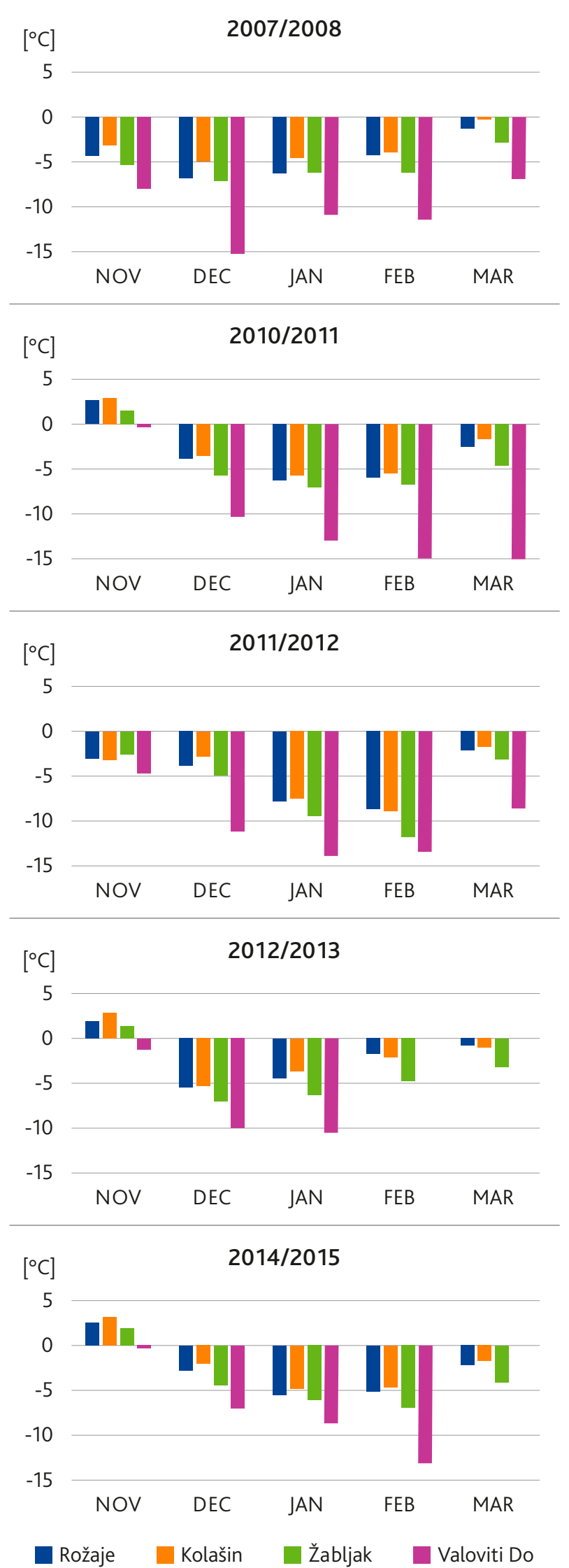

Figure 6. Average minimum air temperatures $\left({ }^{\circ} \mathrm{C}\right)$ at the meteorological stations Rožaje, Kolašin and Žabljak and at the measuring spot Valoviti Do in the 2007/2008, 2010/2011, 2012/2013 and 2014/2015 seasons 
Table 8. Average monthly minimum air temperatures $\left({ }^{\circ} \mathrm{C}\right)$ at the meteorological stations Rožaje, Kolašin and Žabljak and at the measuring spot Valoviti Do in the 2007/2008, 2010/2011, 2012/2013 and 2014/2015 seasons

\begin{tabular}{|l|c|c|c|c|c|}
\hline 2007/2008 & Nov & Dec & Jan & Feb & Mar \\
\hline Rožaje $(1007 \mathrm{~m})$ & -4.4 & -6.8 & -6.3 & -4.4 & -1.4 \\
\hline Kolašin $(944 \mathrm{~m})$ & -3.3 & -5.1 & -4.7 & -4.1 & -0.4 \\
\hline Žabljak $(1450 \mathrm{~m})$ & -5.4 & -7.1 & -6.2 & -6.2 & -3.0 \\
\hline Valoviti Do $(2018 \mathrm{~m})$ & -8.0 & -15.2 & -10.9 & -11.4 & -7.0 \\
\hline 2010/2011 & Nov & Dec & Jan & Feb & Mar \\
\hline Rožaje $(1007 \mathrm{~m})$ & 2.7 & -3.8 & -6.1 & -5.9 & -2.5 \\
\hline Kolašin $(944 \mathrm{~m})$ & 3.0 & -3.5 & -5.6 & -5.4 & -1.6 \\
\hline Žabljak (1450 m) & 1.6 & -5.6 & -6.9 & -6.6 & -4.5 \\
\hline Valoviti Do $(2018 \mathrm{~m})$ & -0.2 & -10.3 & -12.8 & -14.9 & -14.9 \\
\hline 2011/2012 & Nov & Dec & Jan & Feb & Mar \\
\hline Rožaje $(1007 \mathrm{~m})$ & -3.1 & -3.9 & -7.8 & -8.7 & -2.2 \\
\hline Kolašin $(944 \mathrm{~m})$ & -3.3 & -2.9 & -7.5 & -9.0 & -1.9 \\
\hline Žabljak $(1450 \mathrm{~m})$ & -2.6 & -5.0 & -9.5 & -11.8 & -3.2 \\
\hline Valoviti Do $(2018 \mathrm{~m})$ & -4.8 & -11.1 & -13.9 & -13.4 & -8.6 \\
\hline 2012/2013 & Nov & Dec & Jan & Feb & Mar \\
\hline Rožaje $(1007 \mathrm{~m})$ & 1.9 & -5.4 & -4.4 & -1.7 & -0.8 \\
\hline Kolašin $(944 \mathrm{~m})$ & 2.9 & -5.3 & -3.6 & -2.1 & -1.0 \\
\hline Žabljak (1450 m) & 1.4 & -6.9 & -6.2 & -4.7 & -3.1 \\
\hline Valoviti Do (2018 m) & -1.1 & -10.0 & -10.4 & & \\
\hline 2014/2015 & Nov & Dec & Jan & Feb & Mar \\
\hline Rožaje $(1007 \mathrm{~m})$ & 2.5 & -2.9 & -5.5 & -5.1 & -2.2 \\
\hline Kolašin $(944 \mathrm{~m})$ & 3.1 & -2.1 & -4.8 & -4.6 & -1.7 \\
\hline Žabljak (1450 m) & 1.9 & -4.4 & -6.1 & -6.9 & -4.1 \\
\hline Valoviti Do $(2018 \mathrm{~m})$ & -0.3 & -7.0 & -8.6 & -13.1 & \\
\hline
\end{tabular}

the second coldest station was $4.3^{\circ} \mathrm{C}$. The second coldest station was Žabljak in 14 out of 16 instances, and in one instance each Kolašin and Rožaje. Žabljak had an average minimum temperature that was $1.1^{\circ} \mathrm{C}$ lower than the average minimum temperature for Rožaje, and Kolašin was $0.6{ }^{\circ} \mathrm{C}$ warmer than Rožaje (Table 9).

Since the average minimum temperatures take into account all the days in the month, days with an advective type of weather, when the effects of cold air lakes are negligible, also influence the values. During these times, conditions at the lower elevations (Rožaje and Kolašin) are unfavorable for low minimums, and the elevation temperature gradient is also higher. In such cases elevation has a greater role than location with respect to the creation of a cold air lake. This explains the greater difference between the station of Žabljak and the lower lying stations of Rožaje and Kolašin. Likewise the difference between the meteorological station of Žabljak and the measuring spot Valoviti Do is considerably smaller.

Table 9. Average minimum air temperatures $\left({ }^{\circ} \mathrm{C}\right)$ for the 2007/2008, 2010/2011, 2011/2012 and 2014/2015 winter seasons

\begin{tabular}{|l|c|c|}
\hline Station & Elevation $(\mathrm{m})$ & $\mathrm{T}\left({ }^{\circ} \mathrm{C}\right)$ \\
\hline Rožaje & 1007 & -4.3 \\
\hline Kolašin & 944 & -3.7 \\
\hline Žabljak & 1450 & -5.4 \\
\hline Valoviti Do & 2018 & -9.7 \\
\hline
\end{tabular}

* In November 2007 measurements were performed for 28 days (3 - 30 November 2007) and in March 2011 for only 25 days (1 - 25 March 2011)

\section{Conclusion}

The analysis of minimum air temperatures in the 2007/2008, 2010/2011, 2011/2012, 2012/2013 and 2014/2015 winter seasons included the three that are among the coldest meteorological stations in the national network of the Montenegro Hydrometeorological Institute (Žabljak, el. 1450 m; Rožaje, el. 1007 m; Kolašin, el. $944 \mathrm{~m}$ ) and the measuring spot Valoviti Do (el. $2018 \mathrm{~m}$ ) in a high mountain karst depression on Durmitor. It turned out that due to basins and valleys with frequently occurring cold air lakes the average elevation temperature gradient of the interior of Montenegro was less than in coastal areas.

With regard to minimum temperatures, in addition to the elevation of particular stations, their position with respect to concavity or convexity of the surface is also very important. Of the stations in the national meteorological network, the valley location of the stations Rožaje and Kolašin turned out to be an important element in the creation of temperature inversions, which is conducive to lower minimum temperatures that are similar to those of the higher elevation Žabljak.

Minimum temperatures in Valoviti Do in the 2007/2008, 2010/2011, 2011/2012, 2012/2013 and 2014/2015 winter seasons confirmed our hypothesis that in the mountainous parts of Montenegro temperatures can fall considerably lower than the records measured to date, since a large portion of the mountain environment is not included in the regular and systematic temperature measurements of the national meteorological network. In the elevation zone above $1500 \mathrm{~m}$, which represents $15 \%$ of the national territory $(2072 \mathrm{~km} 2)$, there are no meteorological stations, and in the elevation zone above $1000 \mathrm{~m}$ (55\% of the territory) there are only three in operation. The high mountain karst depression of Valoviti Do (el. $2018 \mathrm{~m}$ ) turned out to be colder than all three high elevation meteorological stations in the northern and eastern part of Montenegro (Žabljak, el. 1450 m; Rožaje, el. 
1007 m; Kolašin, el. 944 m), which along with the meteorological station in Plevlja are among the coldest in the network of the Montenegro Hydrometeorological Institute. It is thus not surprising that we measured a temperature of $-4 \mathrm{O}^{\circ} \mathrm{C}$ there on 4 January 2011, which is the lowest recorded air temperature in Montenegro to date.

Based on these measurements we can also conclude that concave mountain areas represent frost hollows with extreme nighttime minimums during anticyclonic weather, in which temperatures frequently drop below $-30{ }^{\circ} \mathrm{C}$ and can even drop as low as below $-40{ }^{\circ} \mathrm{C}$. Within Montenegro, in addition to Durmitor similar conditions can also be expected in the concave landforms of the mountain areas of Sinjajevina, Maganik, the Morača Mountains, Orjen, Lovčen and elsewhere. The authors of the study believe that a more detailed investigation of temperature conditions in mountain basins of Montenegro would reveal an even more detailed and diverse picture of local (topoclimatic) conditions, which are an important ecological and geodiversity factor in Montenegro. With respect to methodology, temperature registrators have been shown to be a reliable and practical measuring tool that is also affordable. However, for areas where temperatures can be expected to drop below $-40{ }^{\circ} \mathrm{C}$, it is essential to use registrators with a measuring range that extends to at least $-50^{\circ} \mathrm{C}$.

\section{Acknowledgments}

The authors would like to thank Golub Culafic from the Montenegro Hydrometeorological Institute for providing data, and students at the Department of Geography of the University of Ljubljana Faculty of Arts and colleagues Gregor Vertačnik, Iztok Sinjur, Dušan Plut, Boštjan Rogelj, Blaž Repe and Dejan Cigale for assistance with research.

\section{References}

Annys, K., Frankl, A., Spalević, V., Čurović, M., Borota, D., \& Nyssen, J. (2014). Geomorphology of the Durmitor Mountains and surrounding plateau Jezerska Površ (Montenegro). Journal of Maps, 10(4), 6oo-611. http://dx.doi.org/10.1080/17445647.2014.90 9338 (accessed 23 April 2017).

Bárány-Kevei, I. (1999). Microclimate of karstic dolines. Acta Climatologica, 32(33), 19-27.

Brönnimann, S., Andrade, M., \& Diaz, H. F. (2014). Climate Change in the European Alps. In Kohler, Thomas; Wehrli, André \& Jurek, Matthias (Eds.) Mountains and Climate Change. A Global Concern (pp. 14-15). Bern: Geographica Bernensia

Burić, D., Ducić, V., \& Luković, J. (2011). Climate variability in Montenegro in second half of the XX and the beginning of the XXI century. Podgorica: Montenegrin Academy of Sciences and Arts

Clements, C. B., Whiteman, C. D., \& Horel, J. D. (2003). Cold-air-pool structure and evolution in a mountain basin: Peter Sinks, Utah. Journal of Applied Meteorology, 42(6), 752-768.

Dozier, J., \& Frew, J. (1990). Rapid calculation of terrain parameters for radiation modeling from digital elevation data. IEEE Transactions on Geoscience and Remote Sensing, 28(5), 963-969.

Djurović, P. (2009). Reconstruction of the Pleistocene glaciers of Mt. Durmitor in Montenegro. Acta Geographica Slovenica, 49(2), 263-289.
Djurovic, P. (2011). Visokoplaninski kras Durmitora [High mountain karst on Durmitor]. Belgrade: Forma $B$.

Djurović, P. (2012). The Debeli Namet glacier (Durmitor, Montenegro)-from the second half of the 2oth century to the present. Acta geographica slovenica, 52(2), 277-301. https://ojs.zrc-sazu.si/ags/article/ view/1357 (accessed 23 April 2017).

Gams, I. (1972): Prispevek k mikroklimatologiji vrtač in kraških polj [A contribution to the microclimatology of the karst dolines and poljes]. Geografski zbornik, 13, 5-79.

Hurrell, J. W. (1995). Decadal trends in the North Atlantic Oscillation: regional temperatures and precipitation. Science, 269(5224), 676-679.

Lareau, N. P., Crosman, E., Whiteman, C. D., Horel, J. D., Hoch, S. W., Brown, W. O., \& Horst, T. W. (2013). The persistent cold-air pool study. Bulletin of the American Meteorological Society, 94(1), 51-63. http://journals.ametsoc.org/doi/abs/10.1175/BAMSD-11-00255.1 (accessed 22 April 2017).

Martinčić, A. (1975). Vpliv človeka na nastanek nekaterih mrazišč v Trnovskem gozdu. Razprave. Posebna številka 1, 35-43. URL: http://www.meteodrustvo.si/data/Arhiv_razprave_papers/razprave/ po_stevilkah/75/simpozij/1/simpozij_75_1_35-43. pdf (accessed 23 April 2017).

Martinčič, A. (1977). Prispevek k poznavanju ekologije mrazišč v Sloveniji.- botanično-ekološka skica [Contribution to the knowledge of the ecology of cold holes 
in Slovenia: botanical-ecological sketch.]. Ljubljana: Slovenska Akademija Znanosti in Umetnosti. 91 p.

Morley, M., \& Woodward, J. (2007). Mediterranean Quaternary rockshelter sediment records: A multi-proxy approach to environmental reconstruction. University of Manchester.

Müller, H., \& Whiteman, C. D. (1988). Breakup of a nocturnal temperature inversion in the Dischma Valley during DISKUS. Journal of applied Meteorology, 27(2), 188-194. http://journals.ametsoc.org/doi/ pdf/10.1175/1520-0450\%281988\%29027\%3C0188\%3A BOANTI\%3E2.o.CO\%3B2 (accessed 23 April 2017).

Natek, K. (2007). Periglacial landforms in the Pohorje Mountains. Dela, 27, 247-263.

National prediction center (2018). National Weather Service. Monitoring Weather \& Climate. URL: http:// www.cpc.ncep.noaa.gov/products/precip/CWlink/ pna/nao_index.html (accessed 23 October 2018)

Ogrin, D., Sinjur, I., \& Ogrin, M. (2006). Extreme temperature minimums in Slovenian Alpine dolines. In Sixth Annual Meeting of the European Meteorological Society (EMS) and Sixth European Conference on Applied Climatography (ECAC). Ljubljana: Slovenia, 4-8 September 2006.

Ogrin, M. (2007). The minimum temperatures in the winter 2006/07 in Slovenian frost hollows and cold basin. Dela, 28, 221-237.

Ortar, J., Ogrin, M., Vertačnik, G., \& Sinjur, I. (2010). Primerjava temperaturnih razmer v mraziščih Reovce (Orjen), Valoviti Do (Durmitor), Luknja in Mrzla Komna (obe Julijske Alpe) v meteorološki zimi 2007/2008. In Geoekologija XXI vijeka: teorijski I aplikativni zadaci : zbornik referata [Geoecology - XXI century: theoretical and applicative tasks: proceedings of the symposium: Proceedings. Nikšić: Filozofski fakultet, pp. 553-561.

Ortar, J. (2011). Tipizacija in regionalizacija slovenskih mrazišč: diplomsko delo (Doctoral dissertation, J.
Ortar). Ljubljana: Oddelek za geografijo, Filozofska fakulteta, $63 \mathrm{p}$.

Petkovšek, Z. (1992). Turbulent dissipation of cold air lake in a basin. Meteorology and Atmospheric Physics, 47(2-4), 237-245.

Radojčić, B. (2008). Geografija Crne Gore Prirodna osnova. Podgorica: Dukljanska akademija nauka i umjetnosti, $355 \mathrm{p}$.

Schmidt, W. (1930). Die tiefsten Minimumtemperaturen in Mitteleuropa. Naturwissenschaften, 18(17), 367-369.

Trošt, A. (2008). Mrazišča na Komni: diplomsko delo. Ljubljana: Oddelek za geografijo, Filozofska fakulteta, $83 \mathrm{p}$.

Whiteman, C. D., Bian, X., \& Zhong, S. (1999). Wintertime evolution of the temperature inversion in the Colorado Plateau Basin. Journal of Applied Meteorology, 38(8), 1103-1117.

Wetterzentrale (2018). Archive of GFS reanalysis. URL: http://www.wetterzentrale.de/reanalysis.php $?$ map $=1 \&$ model $=$ avn\&var $=2 \&$ jaar $=2011 \&$ maand $=$ $01 \& \mathrm{dag}=04 \&$ uur $=0000 \& \mathrm{~h}=0 \& \mathrm{tr}=1440 \& \mathrm{nmaps}=2$ 4\#mapref (accessed 23 October 2018)

Whiteman, C. D., Haiden, T., Pospichal, B., Eisenbach, S., \& Steinacker, R. (2004). Minimum temperatures, diurnal temperature ranges, and temperature inversions in limestone sinkholes of different sizes and shapes. Journal of applied meteorology, 43(8), 1224-1236.

Whiteman, C. D., De Wekker, S. F., \& Haiden, T. (2004). Boundary layer moisture regimes in small closed basins. In 16th Symposium on Boundary Layers and Turbulence, 9 - 13 August 2004, Portland.

Zhong, S., Whiteman, C. D., Bian, X., Shaw, W. J., \& Hubbe, J. M. (2001). Meteorological processes affecting the evolution of a wintertime cold air pool in the Columbia basin. Monthly Weather Revie, 129(10), 2600-2613. 